International Journal of Current Advanced Research

ISSN: O: 2319-6475, ISSN: P: 2319 - 6505, Impact Factor: SJIF: 5.995

Available Online at www.journalijcar.org

Volume 6; Issue 5; May 2017; Page No. 3837-3841

DOI: http://dx.doi.org/10.24327/ijcar.2017.3841.0378

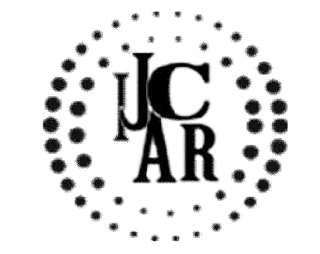

Research Article

\title{
PHYSICAL ADSORPTION OF LIPASE ONTO MESOPOROUS SILICA
}

\section{Abhishek Sharma., Tanvi Sharma., Khem Raj Meena and Shamsher Singh Kanwar}

Department of Biotechnology, Himachal Pradesh University, Summer Hill, Shimla-171 005 India

\begin{tabular}{|c|c|}
\hline A R T I C L E I N F O & A B S T R A C T \\
\hline Article History: & Lipases are versatile enzymes that catalyze the hydrolysis of the ester bonds of lipids. For \\
\hline $\begin{array}{l}\text { Received } 21^{\text {st }} \text { February, } 2017 \\
\text { Received in revised form } 12^{\text {th }} \text { March, } 2017 \\
\text { Accepted } 27^{\text {th }} \text { April, } 2017 \\
\text { Published online } 28^{\text {th }} \text { May, } 2017\end{array}$ & $\begin{array}{l}\text { this study commercial enzyme Lipolase } 100 \mathrm{~L} \text { was studied as a source of lipase. Two silica } \\
\left.\text { preparations, varying in mesh size (Silica }{ }_{70-230} \text { and Silica } 230-400\right) \text {, were used for } \\
\text { immobilisation of Lipolase } 100 \mathrm{~L}(1: 10=\text { lipase: tris buffer). It was observed that activity } \\
\text { assay gave the highest values when treated with } 2 \% \text { of guteraldehyde. } 9 \mathrm{mM} p \text { - NPP gave } \\
\text { the best results as suitable substrate. The enthalpy of activation for silica immobilized }\end{array}$ \\
\hline Key words: & Lineweaver Burk Plot, the values were observed for $\mathrm{S}_{70-230}$ lipolase $\left(K_{\mathrm{m}}=66.67 \mathrm{mM}, V_{\max }\right.$ \\
\hline $\begin{array}{l}\text { Lipase, Immobilization Silica, Kinetic study, } \\
\text { Reusability. }\end{array}$ & $\begin{array}{l}\left.=3.34 \mathrm{U} / \mathrm{mg} / \mathrm{min} ., k_{\text {cat }}=35.22 \mathrm{~s}^{-1} \text { and specificity constant }=10.56 \mathrm{~s}^{-1} \mathrm{Mm}^{-1}\right), \mathrm{S}_{230-400} \text { lipolase } \\
\left(K_{\mathrm{m}}=52.64 \mathrm{mM} \text {, of } V_{\max } \text { is } 2.32 \mathrm{U} / \mathrm{mg} / \mathrm{min} ., k_{\text {cat }}=27.80 \mathrm{~s}^{-1} \text { and specificity constant }=12.00\right. \\
\left.\mathrm{s}^{-1} \mathrm{Mm}^{-1}\right) \text { and pure lipolase enzyme }\left(K_{\mathrm{m}} \text { value as } 62.5 \mathrm{mM}, V_{\max } 2.1875 \mathrm{U} / \mathrm{mg} / \mathrm{min}, k_{\text {cat }}\right. \\
\left.=33.02 \mathrm{~s}^{-1} \text { and specificity constant }=15.09 \mathrm{~s}^{-1} \mathrm{Mm}^{-1}\right) \text {. The thermostability of silica } \\
\text { immobilized showed that the half-life }\left(\mathrm{t}_{1 / 2}\right) \text { of immobilized lipase was approximately } 30 \\
\text { minutes at } 55^{0} \mathrm{C} \text {. Among chelating and denaturing agents like SDS, EDTA, } \\
\text { mercaptoethanol and PEG affected the activity by lowering its value too. The lipase } \\
\text { immobilizes silica is reusable upto } 5 \text { cycles during which it retained it activity upto } 50 \% \text {. }\end{array}$ \\
\hline
\end{tabular}

Copyright $₫ 2017$ Abhishek Sharma et al. This is an open access article distributed under the Creative Commons Attribution License, which permits unrestricted use, distribution, and reproduction in any medium, provided the original work is properly cited.

\section{INTRODUCTION}

A lipase is an enzyme that hydrolyzes the fats like triglycerides into the fatty acid and glycerol molecules. Among biocatalysts microbial lipases have capability to catalyze a variety of reactions in aqueous and non-aqueous media (Rifaat et al., 2010). Lipases are found in the plants, animals and microbes. However, the microbial lipases find immense industrial applications. Lipases are one of the most important groups of biotechnologically relevant enzymes used for application in manufacture of a variety of foods, fine chemicals, detergents, wastewater treatment, cosmetics, paper and pulp, pharmaceuticals and leather industry (Bose, 2014). The reason for the vast biotechnological potential of microbial lipases includes that they are; stable in organic solvents, do not require cofactors, possess a broad substrate specificity (Chandrasekaran and Bhartiya, 2009, Sharma et al., 2016, Sood et al., 2016) and also exhibit a high enantio-selectivity (Holt and Hanefeld, 2009).

Enzyme stability is important in a variety of commercial and industrial applications due to harsh conditions than in the laboratory assays. These drawbacks of the free enzymes are overcome through immobilization technique (Sharma et al., 2014, Sharma et al., 2016, Sood et al., 2016).

*Corresponding author: Abhishek Sharma

Department of Biotechnology, Himachal Pradesh

University, Summer Hill, Shimla-171 005 India their use even under harsh environmental conditions of $\mathrm{pH}$, organic solvents and temperature There are many techniques used for immobilization of the enzymes onto supports which include simple adsorption, covalent attachment, entrapment, crosslinking, surface modification, etc (Tran and Balkus, 2011). The immobilization process can be affected by selection of the optimum support material because its nature, reactive group and interaction with enzymes can affect the enzyme activity. This technique makes use of enzymes in industries more attractive because it offers certain processing advantages over free enzyme that include ease of separation from the reactant and product, improved stability, and continuous operation. The porous nature of the hydrogel and particulate nature of silica or celite allow the solvent and reactants as well as the product(s) to diffuse freely; this enables the substrate to interact with the enzyme easily (Harun et al., 2004). Generally silica has been used as a support due to its thermal, mechanical and chemical stability, biocompatibility, inertness, high hydrophobicity and microbial attacks resistant (Hartmann et al., 2013).

\section{METHODOLOGY}

\section{Chemicals and Source of Lipolase $100 \mathrm{~L}$}

All the chemicals were of analytic grade and were used as received.The enzyme used in the study named Lipolase $100 \mathrm{~L}$ is a commercial lipase enzyme obtained from a strain of bacteria namely Thermomyces langinosus and supplied by 
Novoenzyme A/S (Bagsvaerd, Denmark) as a gift for use in the present study.

\section{Lipase assay}

Lipase activity was assayed in the culture broth by the method of Winkler and Stuckmann, 1979 by measuring the micromoles of $p$-nitrophenol released from $p$-nitrophenyl palmitate. One unit $(\mathrm{U})$ of lipase activity was defined as amount of enzyme required to release one micromole of $p \mathrm{NP}$ from the substrate ( $p N P P$ ) per minute by one $\mathrm{mL}$ or one gram of the immobilized enzyme (including the weight of the matrix) prepared under standard assay conditions. Protein estimation was done by the method of (Bradford, 1976).

\section{Immobilization of lipase on silica matrix}

In a glass beaker, $10 \mathrm{~g}$ of silica was taken to which $50 \mathrm{~mL}$ of Tris buffer ( $0.05 \mathrm{M}, \mathrm{pH}$ 8.5) was poured and incubated for 24 hours at $8^{\circ} \mathrm{C}$ to check the swelling capacity. After a day of incubation $2 \mathrm{~g}$ of silica was taken to which $5 \mathrm{~mL}$ of lipase enzyme $(1: 10=$ Lipolase:tris buffer $)$ was loaded and incubated for 24 hours at $8^{\circ} \mathrm{C}$. Further, $20 \mathrm{~mL}$ of Gluteraldehyde (2\%) was added as a cross linker before incubating for 24 hours at $8^{\circ} \mathrm{C}$. The immobilized protein in matrices was determined by subtracting unbound protein in the supernatant from the total protein used for immobilization as well as increased/decreased total activity was calculated by adding total activity of supernatant and matrix in comparison to total enzyme units in $5 \mathrm{~mL}$ of purified lipase incubated earlier. The matrix that gave higher activity and bound protein was used for further studies.

\section{Effect of different percentage of Gluteraldehyde on the bound lipase activity}

In this study different percentage concentration of Gluteraldehyde $(1,2,3$, and $4 \%$ ) was checked to find the maximum binding capacity of lipolase on the given matrices for a particular percentage of Gluteraldehyde.

\section{Effect of different p- nitrophenyl acyl esters (substrates) on silica-immobilized lipase}

To study the substrate specificity of the silica-immobilized lipase, different chromogenic substrates namely $p$ NPA, $p$ NPB,$p$ NPL, $p$ NPP and $p$ NPS (9 mM each) were used. Each of the above chromogens was prepared by taking $0.04 \mathrm{~g}$ in $10 \mathrm{~mL}$ of $i s o$-propanol. The reaction was performed using 40 $\mathrm{mg}$ of silica-immobilized lipase and Tris buffer $(0.05 \mathrm{M})$ of $\mathrm{pH} 8.5$ at $55^{\circ} \mathrm{C}$ for $10 \mathrm{~min}$.

\section{Effect of reaction temperature on silica-immobilized lipase}

To study the effect of reaction temperature, enzyme activity was assayed at selected each of the reaction temperatures $(35$, $45,55,65$, and $75^{\circ} \mathrm{C}$ ) with $9 \mathrm{mM}$ substrate $(p \mathrm{NPP})$. The reaction was performed using $40 \mathrm{mg}$ of silica-immobilized lipase and Tris buffer $(0.05 \mathrm{M})$ of $\mathrm{pH} 8.5$ for $10 \mathrm{~min}$.

\section{Kinetic study of silica-immobilized lipase}

The $K_{\mathrm{m}}, V_{\max }, K_{\text {cat }}$ and specificity constant of the immobilized lipase(s) was determined by measuring the reaction velocities at the different concentration of the $p$ NPP i.e $2-20 \mathrm{mM}$, the reciprocal of the reaction velocity was plotted against the reciprocal of the substrate concentration to determine the $K_{\mathrm{m}}$ and $V_{\max }$ value by Lineweaver-Burke plot (Lineweaver and Burke, 1934). The reaction was performed using $40 \mathrm{mg}$ of immobilized enzyme and Tris buffer $(0.05 \mathrm{M})$ of $\mathrm{pH} 8.5$ at $55^{\circ} \mathrm{C}$ for $10 \mathrm{~min}$. Activation energy (Ea) was determined from Arrhenius plot (Ghori et al., 2011, Sharma et al., 2016).

\section{Thermostability of silica-immobilized lipase}

To examine the effect of temperature on stability of the immobilized enzyme, enzyme immobilized silica was kept separately in test tubes for different intervals $(0,10,20$ and 30 minutes) at $55^{\circ} \mathrm{C}$. The activity measured immediately before incubation was defined as $100 \%$ of hydrolytic activity. The reaction was performed using $40 \mathrm{mg}$ of silica-immobilized enzyme, $p$ NPP and Tris buffer $(0.05 \mathrm{M})$ of $\mathrm{pH} 8.5$ at $55^{\circ} \mathrm{C}$.

\section{Effect of denaturing/chelating agents on silica-immobilized lipase}

To study the effect of denaturing/ chelating agents on lipase, each of the selected compounds (SDS, EDTA, DTT, mercaptoethanol and PEG; $1 \%(\mathrm{v} / \mathrm{v})$ each) were included separately in reaction mixture. The reaction was performed using $40 \mathrm{mg}$ of silica-immobilized enzyme and Tris buffer $(0.05 \mathrm{M})$ of $\mathrm{pH} 8.5$ at $55^{\circ} \mathrm{C}$ for $10 \mathrm{~min}$.

\section{Effect of organic solvents on silica-immobilized lipase}

The silica-immobilized lipase was assayed in the presence of different $1 \%(\mathrm{v} / \mathrm{v})$ organic solvents viz methanol, ethanol, propane-1-ol, iso-propanol, butane-1-ol, butane-2-ol, pentyl alcohol, hexane-1-ol, octanol, decanol, phenol, $p$-xylene, acetonitrile, DMSO, $n$-pentane, $n$-hexane, $n$-heptane, $n$-octane and $n$-nonane. The reaction was performed using $40 \mathrm{mg}$ of silica-immobilized lipase and Tris buffer $(0.05 \mathrm{M})$ of $\mathrm{pH} 8.5$ at $55^{\circ} \mathrm{C}$ for $10 \mathrm{~min}$.

\section{Reusability of silica-immobilized lipase}

The silica-immobilized enzyme was used for 5 repeated cycles and the reaction was performed using $40 \mathrm{mg}$ of silicaimmobilized lipase and Tris buffer $(0.05 \mathrm{M})$ of $\mathrm{pH} 8.5$ at $55^{\circ} \mathrm{C}$ for $10 \mathrm{~min}$. The silica bound biocatalyst was recovered after each cycle and was used to catalyze a fresh reaction.

\section{RESULTS}

\section{Immobilization of lipase on silica}

Two silica preparations, varying in mesh size (Silica ${ }_{70-230}$ and Silica $230-400)$, were used for immobilisation of S1, S2 Lipolase 100L $(1: 10=$ lipase: tris buffer). In a glass beaker $10 \mathrm{~g}$ of silica was taken to which $50 \mathrm{~mL}$ of tris buffer $(0.05 \mathrm{M}$, pH 8.5) was poured and incubated for 24 hours at $8^{\circ} \mathrm{C}$ to check the swelling capacity. $2 \mathrm{~g}$ of swell silica was taken to which 5 $\mathrm{mL}$ of lipase enzyme $(1: 10=$ Lipolase: tris buffer $)$ was loaded and incubated for 24 hours at $8^{\circ} \mathrm{C}$. Gluteraldehyde $(2 \%)$ was loaded as a cross linker and incubated for 24 hours at $8^{\circ} \mathrm{C}$ before washing it with Tris buffer (Fig. 1).

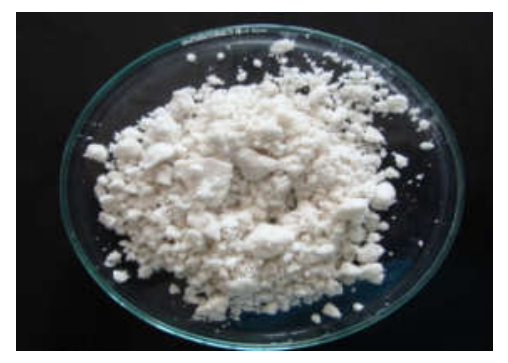

Fig 1 Silica-bound lipase cross linked with glutaraldehyde. 
Effect of different percentage of Gluteraldehyde on silicaimmobilized lipase

To examine the effect of different percentage of Gluteraldehyde $(0 \%, 1 \%, 2 \%, 3 \%$ and $4 \%), 40 \mathrm{mg}$ of immobilized silica was taken (equivalent to $40 \mu \mathrm{L}$ of enzyme put in activity assay) along with $9 \mathrm{mM}$ of $p \mathrm{NPP}$ and Tris buffer $(0.05 \mathrm{M})$ of $\mathrm{pH} 8.5$ at $55^{\circ} \mathrm{C}$ for $10 \mathrm{~min}$, lipase showed maximum activity at the use of $2 \%$ of Gluteraldehyde $\left(\mathrm{S}_{70-230}\right.$ $=73.0 \mathrm{U} / \mathrm{mg}$ and $\mathrm{S}_{230-400}=52.6 \mathrm{U} / \mathrm{mg}$ ).

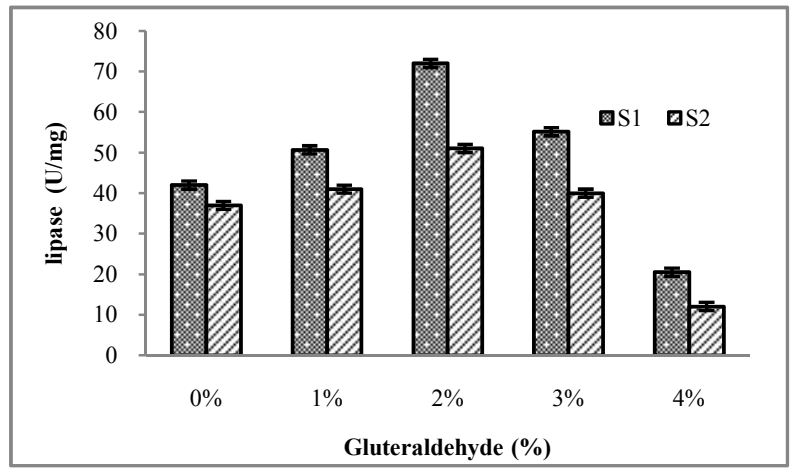

Fig 2 Effect of different percentage of Gluteraldehyde on silicaimmobilized lipase

\section{Effect of different p- nitrophenyl acyl esters (substrates) on silica-immobilized lipase}

To examine the effect of selected $p$-nitrophenyl acyl esters varying in their $\mathrm{C}$-chain length i.e. $p$-nitrophenyl acetate, $p$ nitrophenyl benzoate, $p$-nitrophenyl larute, $p$ - nitrophenyl palmitate and $p$-nitrophenyl stearate, each of these chromogens were separately included in the reaction mixture containing 40 $\mathrm{mg}$ of immobilized silica (equivalent to $40 \mu \mathrm{L}$ of enzyme put in activity assay along with Tris buffer $(0.05 \mathrm{M})$ of $\mathrm{pH} 8.5$ at $55^{\circ} \mathrm{C}$ for $10 \mathrm{~min}$. Both the silica-immobilized lipase preperation showed maximum activity towards $p$ - nitrophenyl palmitate $\left(\mathrm{S}_{70-230}=72.0 \mathrm{U} / \mathrm{mg}\right.$ and $\left.\mathrm{S}_{230-400}=52.1 \mathrm{U} / \mathrm{mg}\right)(\mathrm{Fig}$. $3)$.

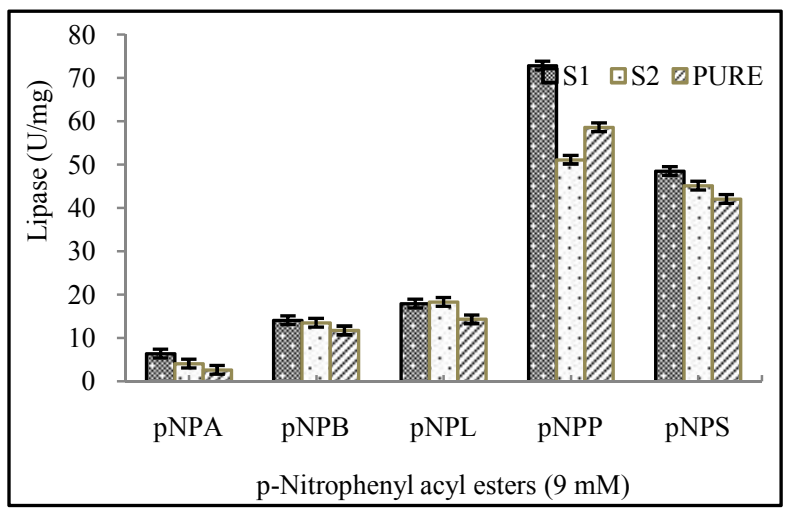

Fig. 3 Effect of different $p$-nitrophenyl acyl esters $(9 \mathrm{mM})$ on silicaimmobilized lipase

\section{Effect of reaction temperature on silica-immobilized lipase}

To examine the effect of reaction temperature on the hydrolytic activity of lipase, $40 \mathrm{mg}$ of immobilized silica was taken (equivalent to $40 \mu \mathrm{L}$ of enzyme put in activity assay) along with $9 \mathrm{mM}$ of $p \mathrm{NPP}$ and Tris buffer $(0.05 \mathrm{M})$ of $\mathrm{pH} 8.5$ for 10 min was incubated separately in the reaction mixture(s) at $35,45,55,65$ and 75 , kept under shaking (130 rpm). For immobilized lipase, the maximum activity $\left(\mathrm{S}_{70-230}=72.9 \mathrm{U} / \mathrm{mg}\right.$ and $\mathrm{S}_{230-400}=52.0 \mathrm{U} / \mathrm{mg}$ ) was recorded at $55 \pm 1^{\circ} \mathrm{C}$ (Fig. 4.6). A further increase in temperature resulted in a gradual decrease in the lipase activity (Fig.4).

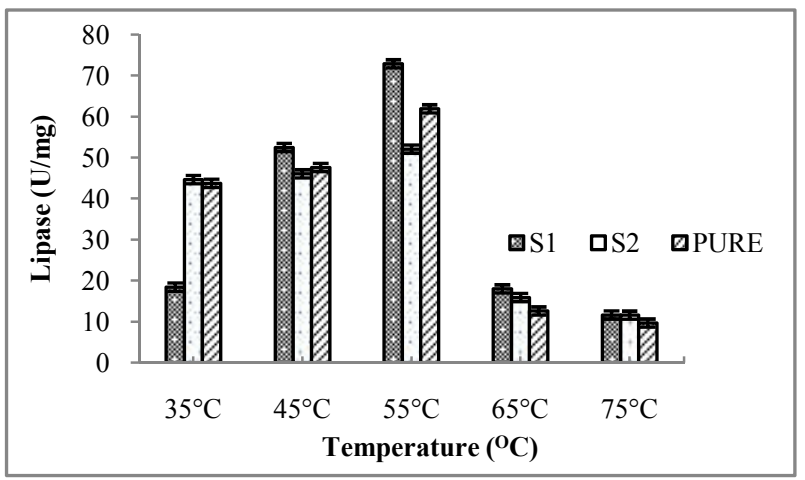

Fig 4 Effect of reaction temperature on silica-immobilized enzyme

\section{Kinetic study of silica-immobilized lipase}

The rate of reaction $V_{\max }$ and $K_{\mathrm{m}}$ using the best colorimetric substrate $p$ NPP were studied by; $40 \mathrm{mg}$ of immobilized silica was taken (equivalent to $40 \mu \mathrm{L}$ of enzyme put in activity assay) along with $9 \mathrm{mM}$ of $p \mathrm{NPP}$ and Tris buffer $(0.05 \mathrm{M})$ of $\mathrm{pH} 8.5$ at $55^{\circ} \mathrm{C}$ for $10 \mathrm{~min} 1-20 \mathrm{mM}$ of $p$ NPP concentration (Fig.8) in $0.05 \mathrm{M}$ Tris-buffer ( $\mathrm{pH} 8.5)$ under shaking at $55 \pm$ $1{ }^{\circ} \mathrm{C}$. A Lineweaver-Burk plot was calibrated to determine $K_{\mathrm{m}}$ and $V_{\max }$ values of immobilized lipase which is in (Fig. 5). Energy of activation $\left(E_{a}\right)$ for lipase was found to be 2.75 $\mathrm{KJmol}^{-1}$.

Table 1 Kinetic study analysis of silica-immobilized lipase

\begin{tabular}{ccccc}
\hline $\begin{array}{c}\text { Biocatalysts } \\
\text { used }\end{array}$ & $\begin{array}{c}\boldsymbol{V}_{\text {max }} \\
(\mathbf{U} / \mathbf{m g} / \mathbf{m i n})\end{array}$ & $\begin{array}{c}\boldsymbol{K}_{\mathbf{m}} \\
(\mathbf{m M})\end{array}$ & $\begin{array}{c}\boldsymbol{K}_{\text {cat }} \\
\left(\mathbf{s}^{-1}\right)\end{array}$ & $\begin{array}{c}\text { Specificity } \\
\text { constant } \\
\left(\mathbf{s}^{-1} \mathbf{m M}^{-1}\right)\end{array}$ \\
\hline $\mathrm{S}_{70-230}$ lipolase & 66.67 & 3.34 & 35.22 & 10.56 \\
$\mathrm{~S}_{230-400}$ lipolase & 52.63 & 2.31 & 27.80 & 12.00 \\
Pure lipolase & 62.50 & 2.18 & 33.02 & 15.09 \\
\hline
\end{tabular}

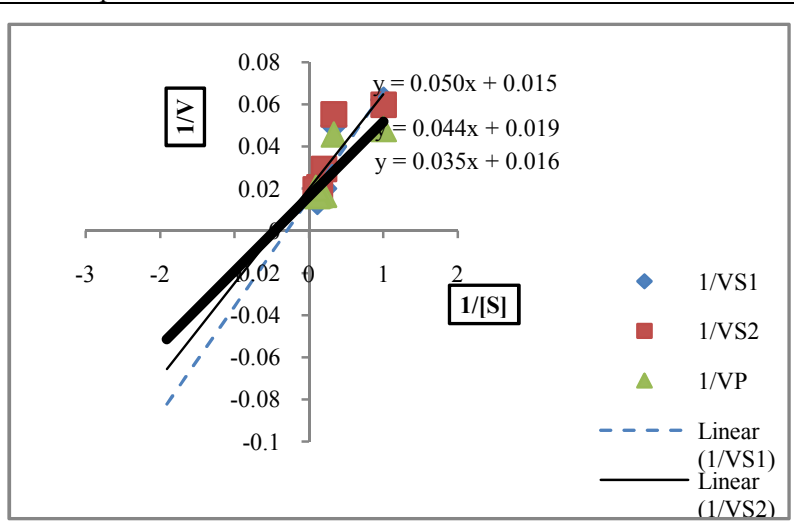

Fig 5 Lineweaver Burk Plot of silica bound lipase using

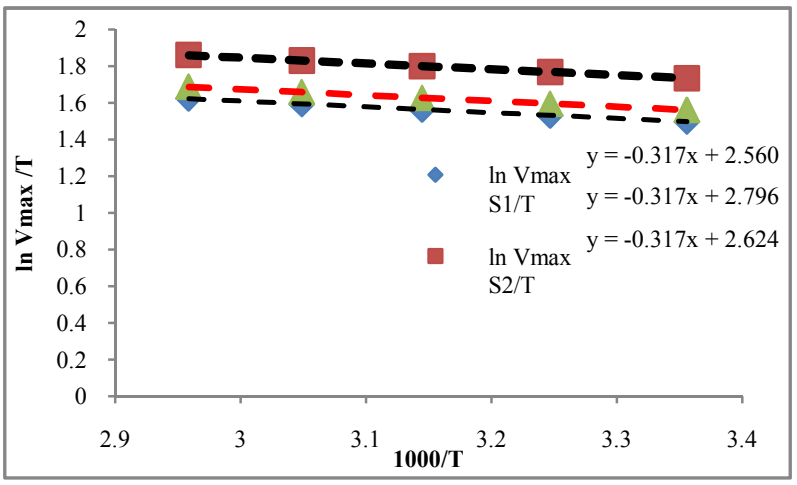

Fig 6 Arrhenius plot for determination of energy of activation of silicaimmobilized lipase 


\section{Thermostability of silica-immobilized lipase at $55^{\circ} \mathrm{C}$}

The thermostability of silica-immobilized lipase was studied by when $40 \mathrm{mg}$ of immobilized silica was taken (equivalent to $40 \mu \mathrm{L}$ of enzyme put in activity assay) along with $9 \mathrm{mM}$ of $p$ NPP and Tris buffer $(0.05 \mathrm{M})$ of $\mathrm{pH} 8.5$ at $55^{\circ} \mathrm{C}$ for $3 \mathrm{~h}$. After 30 minutes, $50 \%$ decrease in the activity of purified along with immobilized lipase was recorded $\left(\mathrm{S}_{70-230}\right.$ having $31.4 \mathrm{U} / \mathrm{mg}, \mathrm{S}_{230-400}$ having $32.7 \mathrm{U} / \mathrm{mg}$ and of pure enzyme was $32.7 \mathrm{U} / \mathrm{mg}$ ) and thus the half-life $\left(\mathrm{t}_{1 / 2}\right)$ of immobilized lipase was approximately 30 minutes at $55^{\circ} \mathrm{C}$.

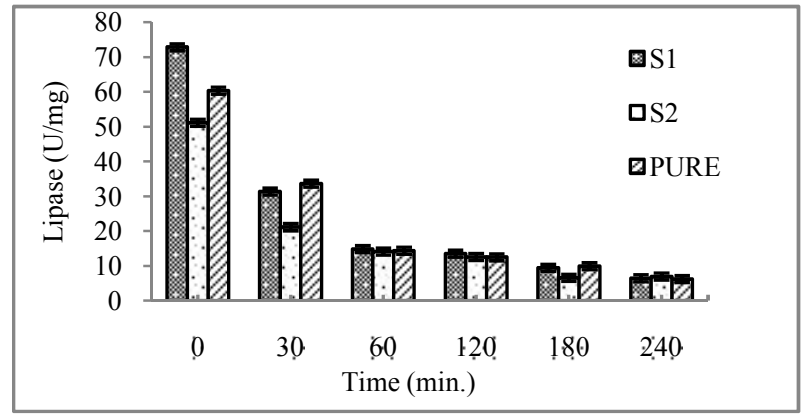

Fig 7 Thermostability of silica-immobilized lipase

Effect of denaturing/chelating agents on silica-immobilized lipase

To study the effect of PEG, DTT, EDTA and Mercaptoethanol each on lipase activity, these were preincubated separately at $1 \%(\mathrm{w} / \mathrm{v})$ concentration with the enzyme $(\mathrm{n}=3)$ at $55 \pm 1{ }^{\circ} \mathrm{C}$ for $10 \mathrm{~min}$ (Fig. 8). The residual lipase activity was assayed thereafter and relative activity in each case was calculated. The mercaptoethanol gave an activity result of silica bound lipase $\left(\mathrm{S}_{70-230}=51.103 \mathrm{U} / \mathrm{mg}\right.$, $\mathrm{S}_{230-400}=51.07 \mathrm{U} / \mathrm{mg}$ ).

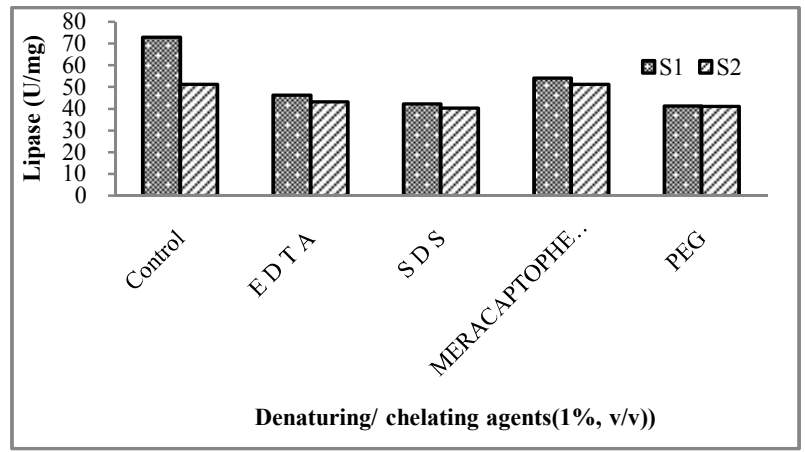

Fig. 8 Effect of denaturating and chelating agents on silica-immobilized lipase

\section{Effect of organic solvents on silica-immobilized lipase}

To study the effect of organic solvents, methanol, ethanol, propane-1-ol, butane-1-ol, butane-2-ol, pentyl alcohol, hexane-1-ol, octanol, decanol, phenol, p-xylene, acetonitrile, DMSO, pentane, hexane, heptane, octane, nonane and isopropane, on silica-immobilized lipase, each of the selected organic solvents was pre-incubated with silica bound lipase $\left(40 \mathrm{mg}\right.$ ) at $55 \pm 1{ }^{\circ} \mathrm{C}$ for $10 \mathrm{~min}$. Lipase activity was assayed at $55 \pm 1{ }^{\circ} \mathrm{C}$ and all showed toxicity towards silica bound lipase. Decanol, DMSO, $n$-nonane and $n$-octane strongly inhibited the activity of immobilized lipase. (Table 2).

\section{Reusability of silica-immobilized lipase}

The immobilized enzyme was used for 5 repetitive cycles with $\sim 50 \%$ loss in activity after $4^{\text {th }}$ cycle (Fig.9).
Table 2 Effect of organic solvents (2\% v/v) on silicaimmobilized lipase

\begin{tabular}{cccccc}
\hline $\begin{array}{c}\text { Organic } \\
\text { solvents }\end{array}$ & logP value & $\begin{array}{c}\text { Activity } \\
\text { (U/mg) }\end{array}$ & $\begin{array}{c}\text { Relative } \\
\text { activity }(\%)\end{array}$ & $\begin{array}{c}\text { Activity } \\
(\mathbf{U} / \mathbf{m g})\end{array}$ & $\begin{array}{c}\text { Relative } \\
\text { activity } \\
(\%)\end{array}$ \\
\hline Control & - & 72.90 & 100 & 51.19 & 100 \\
Methanol & -0.69 & 12.22 & 16.73 & 17.84 & 34.98 \\
Ethanol & -0.58 & 10.64 & 14.58 & 11.51 & 22.56 \\
Propan-1-ol & 0.28 & 58.99 & 80.80 & 55.39 & 108.6 \\
Propan-2-ol & -0.19 & 36.68 & 50.24 & 23.39 & 45.13 \\
Butan-1-ol & 0.61 & 51.36 & 70.35 & 48.19 & 94.49 \\
Butan-2-ol & 0.68 & 44.60 & 61.09 & 29.63 & 58.09 \\
Pentyl alcohol & 1.20 & 25.46 & 34.87 & 42.01 & 82.37 \\
Hexan-1-ol & 1.80 & 13.20 & 18.08 & 25.61 & 50.21 \\
Octanol & 2.91 & 11.36 & 15.56 & 20.57 & 40.33 \\
Decanol & - & 4.46 & 6.10 & 1.87 & 3.66 \\
Phenol & - & 33.23 & 45.52 & 28.63 & 56.13 \\
p-Xylene & 3.1 & 48.91 & 66.99 & 46.76 & 91.68 \\
Benzene & 2.13 & 36.40 & 49.86 & 39.13 & 76.72 \\
Acetonitrile & -0.33 & 27.19 & 37.24 & 32.94 & 64.58 \\
DMSO & -1.22 & 25.03 & 34.28 & 30.50 & 59.80 \\
Pentane & 3.25 & 9.20 & 72.60 & 6.04 & 11.84 \\
Hexane & 3.76 & 30.21 & 41.38 & 23.30 & 45.68 \\
Heptane & 4.27 & 34.09 & 46.69 & 27.62 & 54.15 \\
Octane & 4.78 & 8.92 & 12.21 & 9.78 & 19.17 \\
Nonane & 5.29 & 3.02 & 4.13 & 4.17 & 8.17 \\
\hline & & & & & \\
\hline & & & &
\end{tabular}

The increased reusability, higher $\mathrm{pH}$ and storage stability of immobilized enzyme as compared to the free enzyme would be important for its sustained use and economic viability of biosynthetic processes.

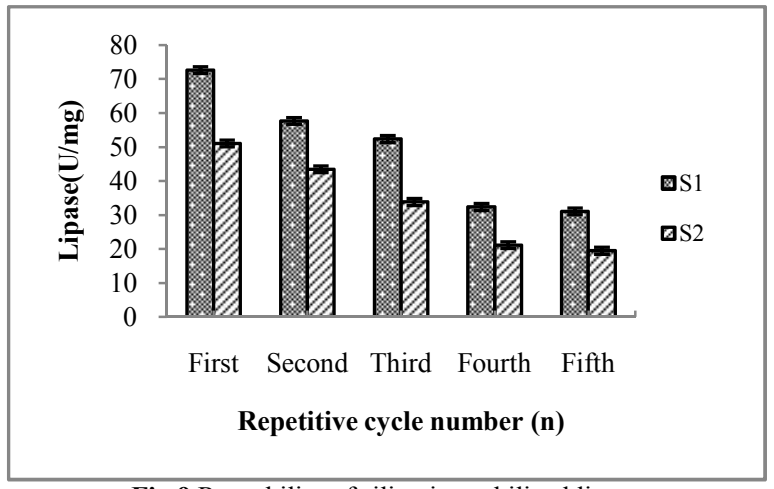

Fig 9 Reusability of silica-immobilized lipase

\section{DISCUSSION}

Lipases have drawn much attention for their potential use in bioprocess, mainly due to their availability and stability in both, aqueous and organic media (Lanka and Lavanya Latha 2015). The interest in microbial lipase production has increased in the last decades, because of its large potential in a wide range of industrial applications as additives in food processing (flavor modification), fine chemicals (synthesis of esters), detergents (hydrolysis of fats), waste water treatment (decomposition and removal of oil substances), diagnostics, cosmetics (removal of lipids), pharmaceuticals (digestion of oil and fats in foods), leather (removal of lipids from animal skin) and medical assays (blood triglyceride assay). The lipase after immobilization onto silica was exposed to glutaraldehyde that acts as a cross-linking agent and is effective against dilution induced dissociation of enzyme (Zhang et al., 2004). Lipase-immobilized by surface adsorption onto silica when pre-treated with $1 \%$ glutaraldehyde showed $89 \%$ binding of protein (Chandel et al., 2015), as compared to $2 \%$ glutaraldehyde which showed 
$96 \%$ bnding in Silica $70-230$ and $80 \%$ Silica $_{230-400}$ observed in this study.

When lipase activity was determined with the use of $p$ NPP, $p \mathrm{NPL}$ and $p \mathrm{NPB}$ as substrates, a unit of activity (UpNP) was expressed as the quantity of enzyme preparation that released $1 \mathrm{mM}$ of p-nitrophenol per $1 \mathrm{~min}$ in the reaction conditions. Standard assays were performed at $30^{\circ} \mathrm{C}$, using $p$ NPP as the substrate (Krakowiak et al., 2003). Whereas, in this study selected $p$-nitrophenyl acyl esters varying in their $\mathrm{C}$-chain length i.e. $p \mathrm{NPA}, p \mathrm{NPB}, p$-NPP, $p \mathrm{NPL}$ and $p \mathrm{NPS}$. Both the silica immobilized lipase preperation showed maximum activity towards $p \mathrm{NPP}\left(\mathrm{S}_{70-230}=72.0 \mathrm{U} / \mathrm{mg}\right.$ and $\mathrm{S}_{230-400}=52.1$ $\mathrm{U} / \mathrm{mg}$ ) when taken at a concentration of $9 \mathrm{mM}$.

During the 1st, 2nd, 3rd, 4th, and 5th cycles of loading of silica with the enzyme, the protein-binding on the silica achieved $51.73 \%, 48.27 \%, 26.92 \%, 10.73 \%$, and $4.29 \%$, respectively (Kumar et al., 2013). The immobilized enzyme was used for 5 repeated cycles with $\sim 50 \%$ loss in activity after $4^{\text {th }}$ cycle when observed in this study.

\section{Concluding remarks}

In this work, the use of a simple approach to employ a cheap silica support to achieve stable binding of a commercial lipase by cyclic adsorption of lipase followed by glutaraldehyde cross-linking was successfully demonstrated. Thus, after immobilisation and optimisation of immobilisation paraneters it was observed that there was a significant increase in the activity of the pure enzyme Lipolase $100 \mathrm{~L}$.

\section{Acknowledgements}

The financial support in the form of DST-JRF to one of the authors (AS) in the form of a Junior Research Fellowship by Department of Science and Technology, New Delhi (India) is thankfully acknowledged

\section{Conflict of interest}

The authors declare no conflict of interests publishing this article in this journal.

\section{Ethical statement}

This article does not contain any studies with human participants or animals performed by any of the authors.

\section{References}

Bose S (2014). A Broader View: Microbial Enzymes and their relevance in Industries, Medicine, and beyond. Research Gate. 64, 18-23.

Bradford MM (1976). A rapid and sensitive method for the quantitation of microgram quantities of protein utilizing the principle of protein-dye binding. Analytical Biochemistry. 72, 248-254.

Chandel C, Kumar A and Kanwar SS (2015). Enzymatic Synthesis of Butyl Ferulate by Silica-Immobilized Lipase in a Non-Aqueous Medium. Journal of Biomaterials and Nanobiotechnology.1, 400-401.

Chandrasekeran SM and Bhartiya S (2009). Substrate specificity of lipase in alkoxycarbonylation reaction: QSAR model development and experimental validation. Biotechnology Bioenginerring. 30, 527-534.
Ghori MI, Iqbal J and Hameed A (2011). Characterization of a novel lipase from Bacillus sp. isolated from tannery wastes. Brazillian Journal of Microbiology. 42, 22-25.

Hartmann M and Kostrov X (2013). Immobilization of enzymes on porous silicas-benefits and challenges. Chemical Society Review. 42, 6277-6289.

Harun A, Basri M, Ahmad MB, and Salleh AB (2004). Enantioselective esterification reaction using immobilized Candida rugosa lipase on poly(N-vinyl-2-pyrrolidone-co-styrene)

hydrogel, Journal of Applied Polymer Science. 92, 3381-3386.

Holt J and Hanefeld Uf (2009). Enantioselective enzymecatalyzed synthesis of cyanohydrins. Current Organic Synthesis. 6, 1005-1018.

Krakowiak A, Trzcifska M, Sieliwanowicz B, Ukowska RS, Jdrychowska B and Ajzenberg V (2003). Properties of immobilized and free lipase from Rhizopus cohnii Polish Journal of food and nutrition sciences. 21, 39-44.

Kumar A, Sharma V, Sharma P and Kanwar SS (2013) . Effective immobilisation of lipase to enhance esterification potential and reusability. Chemical Papers- Slovak Academy of Sciences. 67, 696-702.

Lanka S, Lavanya Latha JN (2015).Purification and characterization of a new cold active lipase, EnL A from Emericella nidulans NFCCI 3643. African Journal of Biotechnology. 2,1899-1900.

Lineweaver H and Burk D (1934). The determination of enzyme dissociation constants. Journal of American Chemical Society. 56, 658-666.

Rifaaat HM, El-Mahalawy AA, El-Menofy HA and Donia SA (2010). Production, optimization and partial purification of lipase from Fusarium oxysporum. Journal of Applied Science and Environmental Sanitation. 5, 39-53.

Sharma S and Kanwar SS (2014). Organic Solvent Tolerant Lipases and Applications. The Scientific World Journal. 5, 1- 3.

Sharma T, Sharma A, Kanwar SS (2016). Purification and characterization of an extracellular mass esterase from Bacillus pumilus, J. Advance Biotechnol. Bioengg. 4 (2016) 9-16.

Sood S, Sharma A, Sharma N and Kanwar SS (2016). Carboxylesterases: sources, characterization and broader applications. Insight enzy. res. 1 (2016)1-11.

Tran DN, Balkus KJ (2011). Perspective of recent progress in immobilization of enzymes. ACS Catalaysis. 1:956968.

Winkler UK and Stuckmann M 1979. Glucogen hyaluronate and some other polysaccharides greatly enhance the formation of exo lipase by Serratia marcescens. Journal of Bacteriology. 138, 663-670.

Zhang XY, Chen XL, Liu W, Zhang YZ, Zhou BC (2004). The stabilization effect of glutaraldehyde on Spirulina platensis phycobilisomes. Chinese Chemical Letters. 15, 1083- 1086. 